\title{
Study of the Surface Charge of a Porous Clay Heterostructure (PCH) and Its Adsorption Capacity of Alkaline Metals
}

\author{
Sofía Arellano-Cárdenas, ${ }^{1}$ Tzayhrí Gallardo-Velázquez, ${ }^{1 *}$ Guillermo Osorio-Revilla, ${ }^{2}$ and Ma. del Socorro \\ López-Cortez ${ }^{1}$ \\ ${ }^{1}$ Departamento de Biofísica. Escuela Nacional de Ciencias Biológicas del Instituto Politécnico Nacional. Plan de Ayala y Carpio, \\ s/n. Col. Casco de Santo Tomás. México, 11340. D. F. Phone: (55) 57296000 ext. 62305. tgallard@encb.ipn.mx \\ 2 Departamento de Ingeniería Bioquímica. Escuela Nacional de Ciencias Biológicas del Instituto Politécnico Nacional.
}

Received February 3, 2010; accepted April 21, 2010

\begin{abstract}
A Porous Clay Heterostructure (PCH) was prepared by chemical modification of a natural clay, by intercalation of a cationic surfactant. Its surface charge properties as well as its adsorption capacity for alkali metals were studied using a potentiometric titration method. The PCH developed a $\mathrm{pH}$-dependent charge $\left(\sigma_{\mathrm{H}}\right)$, probably due to the presence of amphoteric silanol groups $\left(\mathrm{SiO}_{2}\right)$ coming from the pillars of silica interlayered during the pillared process. The PCH presented a region of zero charge in the range of $\mathrm{pH}$ of 4.0 to 7.7. The $\sigma_{\mathrm{H}}$ acquired by the $\mathrm{PCH}$ was adjusted with good correlation to the electric double layer model of Gouy-Chapman $\left(r^{2}=0.9925\right)$. The surface charge conferred the $\mathrm{PCH}$ ion exchange capacity for the studied metals ( $\mathrm{Li}, \mathrm{Na}, \mathrm{K}, \mathrm{Rb}$ and $\mathrm{Cs})$ at high $\mathrm{pH}$ values $(10<\mathrm{pH})$, in comparable quantities (3.5 to $6 \mathrm{meq} / \mathrm{g}$ ) to some Dowex resins. The results of this study suggest that PCH could have applications in the recovery of toxic metals from waste waters.
\end{abstract}

Key words: clay, $\mathrm{PCH}$, metal adsorption, surface charge.

\section{Introduction}

It is known that contamination of aquatic media damage the ecosystems and human life. Among the highly dangerous inorganic contaminants are the heavy metals, which are able to bioaccumulate in the human organism reaching toxic levels that harm nervous central system, liver and kidneys [1].

A wide variety of techniques to remove toxic metals from water are available, such as ion exchange, reverse osmosis and nanofiltration, precipitation, coagulation, oxidation and adsorption. This last technique is very popular due to its high efficiency and low cost. Several adsorbents can be used to remove metal ions, including activated carbons, alumina, silica, bentonite, peat, chitin and ion exchange resins [2,3].

Recently, the progress in the synthesis of nanostructured materials opens a new area for developing functional adsorbents that can remove toxic metals from aqueous solutions.

Since the discovery of Mobil Catalytic Material in 1992 (MCM) [4], a lot of research has been conducted on mesoporous materials. In 1995 Galarneau et al. [5] applied the MCM technology on natural fluorohectorite clay, obtaining a large pore clay derivative, designated as Porous Clay Heterostructure $(\mathrm{PCH})$ material. In the synthesis of a $\mathrm{PCH}$, the clay is firstly opened up by the introduction of an ionic surfactant (via a cation exchange reaction). Neutral amine co-surfac-
Resumen: Se preparó una arcilla porosa de estructura heterogénea $(\mathrm{PCH})$ mediante la modificación química de una arcilla natural, intercalando un surfactante catiónico. Se estudiaron sus propiedades de carga superficial así como su capacidad de adsorción de metales alcalinos utilizando un método de titulación potenciométrica. La PCH desarrolló carga dependiente del $\mathrm{pH}\left(\sigma_{\mathrm{H}}\right)$, debido probablemente a la presencia de grupos silanol $\left(\mathrm{SiO}_{2}\right)$ provenientes de los pilares de silica intercalados durante el proceso de pilarización. La PCH presentó una región de carga cero en el intervalo de $\mathrm{pH}$ de 4.0 a 7.7. La $\sigma_{\mathrm{H}}$ adquirida por la $\mathrm{PCH}$ se ajustó con buena correlación al modelo de doble capa eléctrica de Gouy-Chapman $\left(r^{2}=0.9925\right)$. Esta carga superficial le confirió capacidad de intercambio iónico de los metales estudiados ( $\mathrm{Li}, \mathrm{Na}, \mathrm{K}, \mathrm{Rb}$ y $\mathrm{Cs}$ ) a valores de $\mathrm{pH}$ altos $(10.0<\mathrm{pH})$, en cantidades comparables $(3.5$ a $6 \mathrm{meq} / \mathrm{g})$ con algunas resinas Dowex. Los resultados de este estudio sugieren que la $\mathrm{PCH}$ puede tener aplicación en la remoción de metales tóxicos presentes en aguas residuales.

Palabras clave: arcilla, PCH, adsorción de metales, carga superficial.

tant molecules are then intercalated along with silica species, which leads to self assembly of the silica around micellar template of surfactant and co-surfactant. After calcination for the removal of organic material, the porous network within interlayer region is being formed [6,7]. $\mathrm{PCH}$ is of particular attention, due to its high surface area $\left(250-1000 \mathrm{~m}^{2} / \mathrm{g}\right)$, a combination of micro and mesoporosity and also, a good thermal stability and mechanical strength [5].

Since the first preparation of the PCH material in 1995, research has been conducted mainly to study its potential as heterogeneous acid catalyst [5,7-11]. Also, hydrophobic derivatives of $\mathrm{PCH}$ have been reported, as a new class of inorganicorganic hybrid $\mathrm{PCH}$, prepared through the surfactant directed assembly of organosilica in the galleries of montmorillonite [12]. These materials have demonstrated adsorption capacity of volatile organic compounds (VOCs) [13].

$\mathrm{pH}$-dependent ion exchange and adsorption of aqueous metals capacities of Pillared Interlayered Clay (PILC) and MCM materials, precursors of $\mathrm{PCH}$, have been studied [3,14-20]. However, there are few studies of PCH's surface charge and metal adsorption properties. In 1998, Mercier and Pinnavaia [21] prepared a functionalized 3-mercaptopropyltrimethoxysilane $\mathrm{PCH}$ that binds $\mathrm{Hg}^{2+}$ ions from solution. In 2001, Bejenlloun [22] studied the cation exchange capacitie (CEC) of two PCHs, derived from a natural montmorillonite 
and synthetic saponite. As well, the removal capacity of $\mathrm{Cd}$, $\mathrm{Cu}, \mathrm{Mn}, \mathrm{Ni}$ and $\mathrm{Pb}$ with functionalized thiol grafted $\mathrm{PCH}$, was demonstrated in 2008 by Tassanapayak [23].

This work contributes to the evaluation of the surface charge of a PCH, explaining the experimental results by application of the electric double layer theory of Gouy-Chapman. Also its adsorption capacity of alkaline metals from aqueous solutions was estimated [24,25].

\section{Results and Discussion}

\section{CEC results}

The CEC of the original clay obtained was $75 \mathrm{meq} / 100 \mathrm{~g}$, this value falls within the range reported for the smectite clay (70 to $130 \mathrm{meq} / 100 \mathrm{~g}$ ) [26], which suggest that the clay used belongs to this group. The PCH presented a residual CEC of $20 \mathrm{meq} / 100 \mathrm{~g}$, because most of the exchangeable cations were displaced by the surfactant molecules during the preparation process. The residual CEC represents the net permanent structural charge of the $\mathrm{PCH}\left(\mathrm{s}_{0}\right)$ [27].

\section{pH-dependent charge $\left(\sigma_{H}\right)$}

The adsorption isotherms of $\mathrm{Na}^{+}$and $\mathrm{Cl}^{-}$for two ionic strengths of $\mathrm{NaCl}$, are shown in figure 1 . The profile of the curves suggests the presence of $\mathrm{pH}$-dependent charge $\left(\sigma_{\mathrm{H}}\right)$, which maybe due to the superficial silanol groups $(\mathrm{Si}-\mathrm{OH})$ in the silicon oxide pillars intercalated during the preparation of the $\mathrm{PCH}$; the presence of these groups have been demonstrated on the surface of MCM material [17] and in the silica $\left(\mathrm{SiO}_{2}\right)$ [27], precursors of the $\mathrm{PCH}$.

It may be possible that an ion exchange process can be carried out similar to that observed in amphoteric hydrous oxides $[27,28]$ :

$$
\begin{aligned}
& \equiv \mathrm{Si}-\mathrm{OH}+\mathrm{Cl}^{-} \stackrel{\mathrm{H}^{+}}{\longrightarrow} \equiv \mathrm{Si}-\mathrm{OH}^{2+} \mathrm{Cl}^{-} \\
& \equiv \mathrm{Si}-\mathrm{OH}+\mathrm{Na}^{+} \stackrel{\mathrm{OH}^{-}}{\longrightarrow} \equiv \mathrm{Si}-\mathrm{O}^{-} \mathrm{Na}^{+}
\end{aligned}
$$

Anion exchange (case 1) is favored by low $\mathrm{pH}$, while cation exchange (case 2) is favored at high $\mathrm{pH}$.

It is remarkable that the curves do not cross over in a point, as it happens in the case of oxides [28] and Al-PILCS [18]. Rather, they overlapped in a pH range (4.0 to 7.7), which would represent the region of zero charge, in which the silanol groups would mainly conserve their neutral proton form.

These results are in accordance with those reported by Goyne [27] who found that silica $\left(\mathrm{SiO}_{2}\right)$ showed negligible ionic adsorption in the $\mathrm{pH}$ range of 2.82 to 7.0 , and non anion exchange capacity at any $\mathrm{pH}$. However, the $\mathrm{PCH}$ exhibited anion exchange capacity (figure 1), with a maximum value of $3.1 \mathrm{meq} / \mathrm{g}$ for $\mathrm{Cl}^{-}$at equilibrium $\mathrm{pH}$ of 1.82 (ionic strength of $\mathrm{NaCl} 0.1 N$ ), which could be due to the high basic character

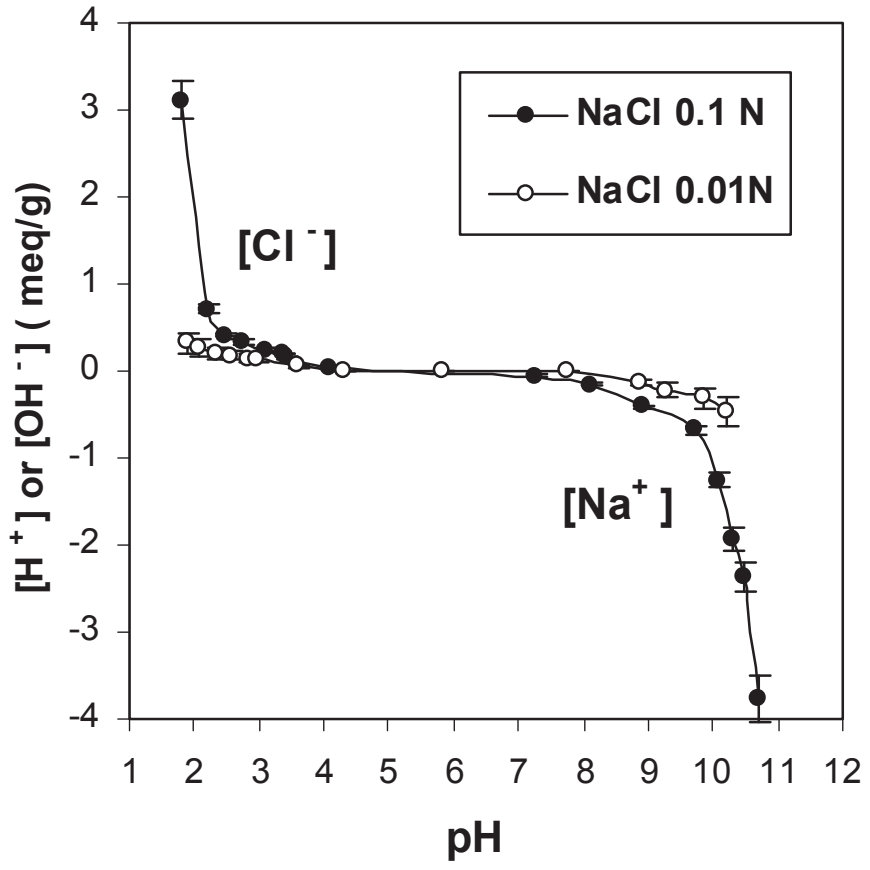

Fig. 1. Anion and cation adsorption isotherms for $\mathrm{NaCl}$ at two ionic strengths, on $\mathrm{PCH}$.

developed by the silanol groups of the $\mathrm{PCH}$ in comparison with the silica.

At high $\mathrm{pH}$, the maximum ion exchange capacity of the $\mathrm{PCH}$ was $3.8 \mathrm{meq} / \mathrm{g}$ for $\mathrm{Na}^{+}$at $\mathrm{pH} 10.7$. Therefore, residual CEC $(0.2 \mathrm{meq} / \mathrm{g})$ contributed only $4.8 \%$ to the total cation exchange capacity of the $\mathrm{PCH}$.

The maximum cation exchange capacity reported for the $\mathrm{SiO}_{2}$ was $9.1 \mathrm{meq} / \mathrm{g}$ at $\mathrm{pH}$ of 9.7 [27]. It is probably that the lower ion exchange capacity of the PCH was due to its lower surface area $\left(305.5 \mathrm{~m}^{2} / \mathrm{g}\right)$ with respect to that reported for the silica $\left(700 \mathrm{~m}^{2} / \mathrm{g}\right)$.

\section{Adsorption of alkaline metals by PCH}

The profile of the adsorption isotherms for the alkaline metal series was characteristic of a $\mathrm{pH}$-dependent charge (figures 2 and 3). Figure 4 shows the comparison of maximum cation exchange capacities of the studied metals and the equilibrium $\mathrm{pH}$ at which they were obtained. $\mathrm{PCH}$ presented larger capacity of adsorption for cesium and rubidium, with values of 5.2 and $5.9 \mathrm{meq} / \mathrm{g}$, respectively, compared with the other metals (in meq/g): $\mathrm{K}^{+}$(4.7), $\mathrm{Na}^{+}$(3.8) and $\mathrm{Li}^{+}$(3.5). The order of adsorption capacity found was inverse to the hydrous radii of ions (in $\AA$ ) $\mathrm{Cs}^{+}$(3.29), $\mathrm{Rb}^{+}$(3.29), $\mathrm{K}^{+}$(3.31), $\mathrm{Na}^{+}$(3.58) and $\mathrm{Li}^{+}$(3.82) [29], thus indicating that the solvation water molecules, can diminish the electrostatic interactions of the cations with the silanol groups.

The cation exchange capacity of the $\mathrm{PCH}$ for the studied metals was higher that the maximum capacity of silica gel reported by Tran [30] for the exchange of metals $\mathrm{Pb}$ (II), $\mathrm{Cu}$ 


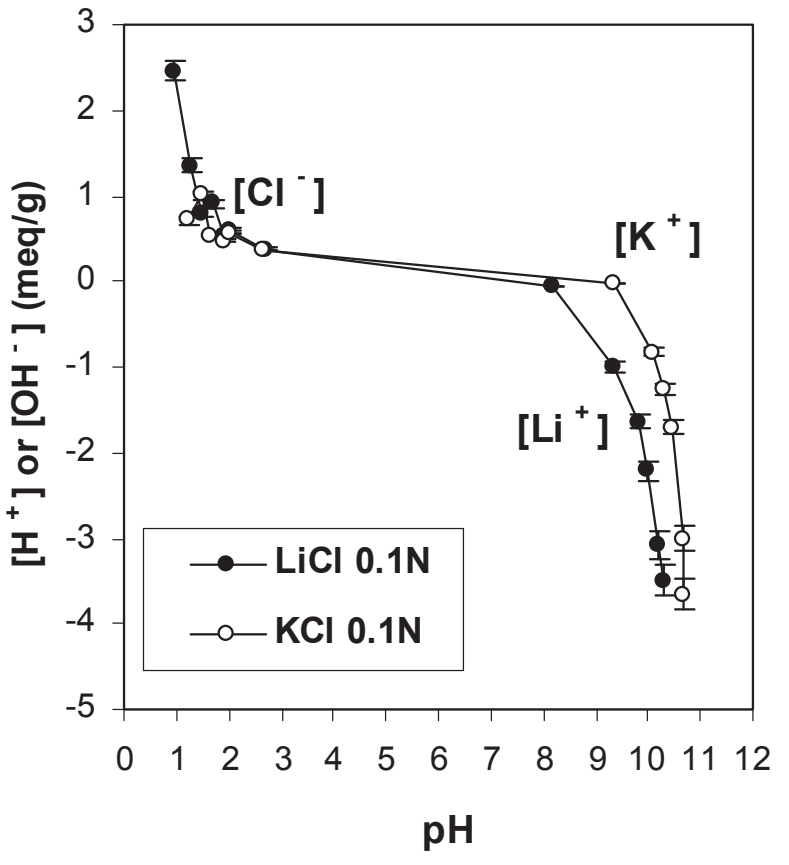

Fig. 2. Anion and cation adsorption isotherms for $\mathrm{LiCl}$ and $\mathrm{KCl}$ at $0.1 N$ on $\mathrm{PCH}$.

(II), Ni (II), Zn (II), Cd (II) and U(VI), with values of 0.009, $0.0082,0.0076,0.0068,0.0059$, and $0.4114 \mathrm{mmol} / \mathrm{g}$, respectively, at $\mathrm{pH}$ of 6.5 . The exchange capacity also was slightly higher than that reported by Dyer and Gallardo [15] for a Zr-PILC, of $3.1 \mathrm{meq} / \mathrm{g}$ for the $\mathrm{Cs}^{+}$and $3.5 \mathrm{meq} / \mathrm{g}$ for the $\mathrm{Rb}^{+}$, at equilibrium $\mathrm{pH}$ of 12.0. Also, the capacity obtained for the $\mathrm{PCH}$ is in the order of the capacity reported for the Dowex resins $(4-5 \mathrm{meq} / \mathrm{g})[31]$.

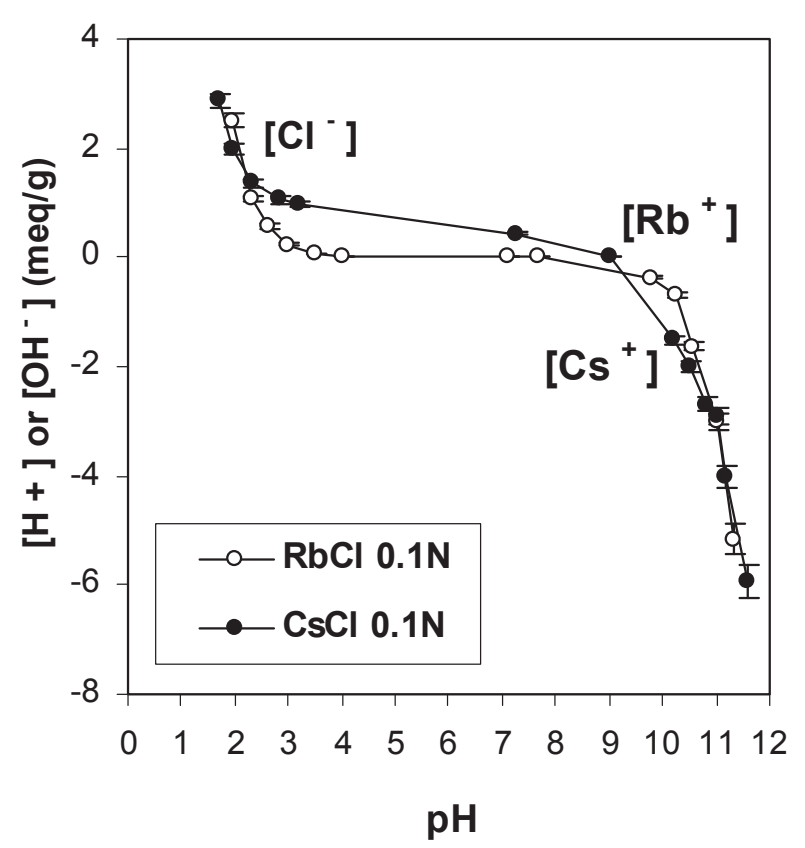

Fig. 3. Anion and cation adsorption isotherms for $\mathrm{CsCl}$ and $\mathrm{RbCl}$ at $0.1 N$ on $\mathrm{PCH}$.

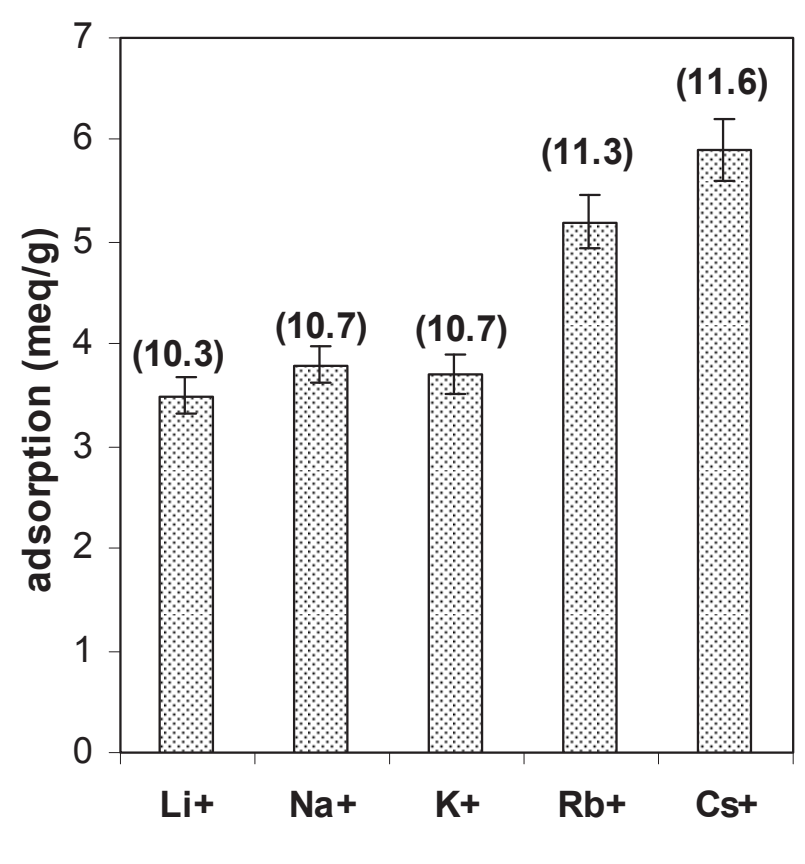

Fig. 4. Comparison of the maximum cation exchange capacity for the $\mathrm{PCH}$. Numbers in brackets indicate the equilibrium $\mathrm{pH}$ at which these maxima were obtained.

\section{Applying the Gouy-Chapman Model}

The adsorption isotherm for $\mathrm{NaCl} 0.1 N$ was adjusted to the electric double layer theory of Gouy-Chapman (equation 3) [16,29]:

Where:

$$
\sigma_{H}=\left(2 n^{o} D k T / \pi\right)^{1 / 2} \operatorname{senh}\left(z e \psi_{o} / 2 k T\right)
$$

$\sigma_{\mathrm{H}}: \mathrm{pH}-\mathrm{dependent}$ surface charge in esu $/ \mathrm{cm}^{2}(\mathrm{esu}=$ electrostatic unities).

$\mathrm{n}^{\mathrm{o}}$ : counter ion concentration in ions $/ \mathrm{cm}^{3}=$ normality $\times$ $10^{-3} \times 6.02 \times 10^{23}$.

D: dielectric constant $=80 \mathrm{esu}^{2} / \mathrm{dn} \cdot \mathrm{cm}^{2}$.

$z$ : ion valence.

$k$ : Boltzmann constant $=1.38 \times 10^{-16} \mathrm{erg} / \mathrm{ion} \cdot \mathrm{K}$.

$T$ : temperature in $\mathrm{K}$.

$\psi_{\mathrm{o}}$ : surface potential in erg/esu.

e: electron charge $=4.8 \times 10^{-10} \mathrm{esu} /$ ion.

$\pi: 3.14159$

The surface electric potential $\left(\psi_{\mathrm{o}}\right)$ was calculated by the Nernst relationship (equation 4) $[16,29]$, assuming that the surface charge was originated only from the adsorption of $\mathrm{H}^{+}$ and $\mathrm{OH}^{-}$:

$$
\psi_{o}=(R T / F) \ln \left(\left[H^{+}\right]-\left[H^{+}\right]_{Z P C}\right)
$$




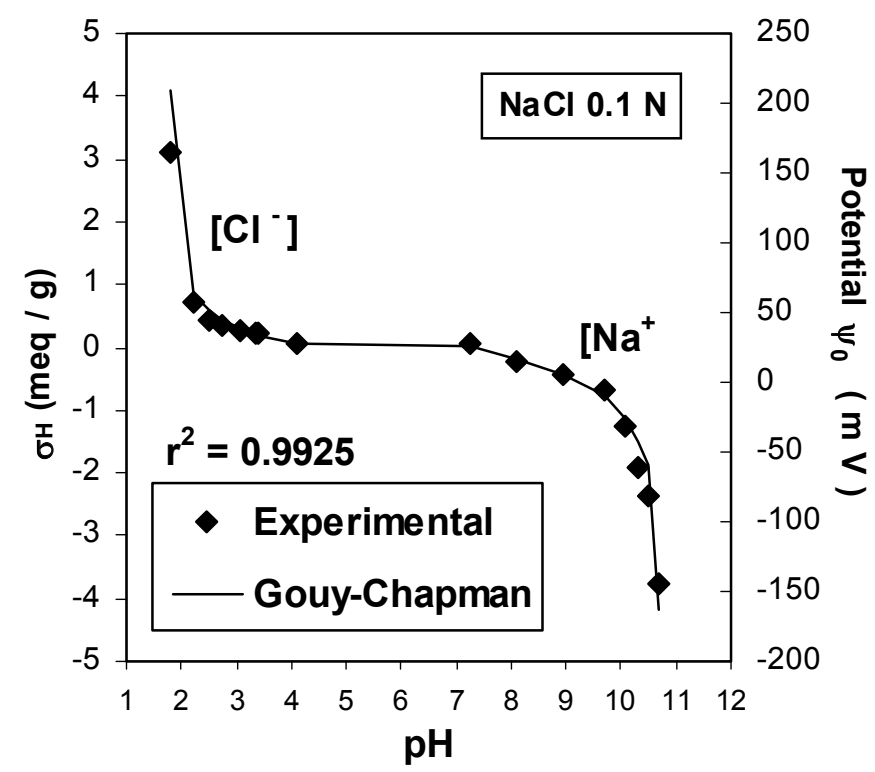

Fig. 5. Comparison of the surface charge of $\mathrm{PCH}$ as determined by potentiometric tritation for $\mathrm{NaCl} 0.1 \mathrm{~N}$ with that calculated by the Gouy-Chapman theory. $r^{2}$ : determination coefficient; $\sigma_{\mathrm{H}}$ : $\mathrm{pH}$-dependent charge $(\mathrm{meq} / \mathrm{g}) ; \psi_{\mathrm{o}}$ : surface potential $(\mathrm{mV})$.

Where:

$\psi_{\mathrm{o}}$ : surface potential in $\mathrm{mV}$.

$R=$ gas constant $=8.314 \mathrm{~J} / \mathrm{mol} \mathrm{K}$.

$F=$ Faraday constant $=96500 \mathrm{~J} / \mathrm{mol}$.

$T=$ temperature in $\mathrm{K}$.

$\left[\mathrm{H}^{+}\right]=$proton concentration in $\mathrm{mol} / \mathrm{l}$.

$\left[\mathrm{H}^{+}\right]_{\mathrm{ZPC}}=$ proton concentration at the zero point of charge in $\mathrm{mol} / \mathrm{l}$.

Where $1 \mathrm{mV}=3.336 \times 10^{-6} \mathrm{erg} / \mathrm{esu}$ and $1 \mathrm{meq} / \mathrm{cm}^{2}=2.89$ $\times 10^{-11} \mathrm{esu} / \mathrm{cm}^{2}$.

The adsorption isotherm for $\mathrm{NaCl} 0.1 \mathrm{~N}$ (figure 5) presented a good correlation $\left(r^{2}=0.9925\right)$ with the calculated curve using the Gouy-Chapman model. In agreement with this theory, the $\mathrm{H}^{+}$and $\mathrm{OH}^{-}$ions originating by the silanol groups, will supposedly conform the fix layer and will determine the $\sigma_{\mathrm{H}}$. This superficial charge can acquire positive $(\mathrm{pH}<$ 4.0) and negative values $(7.7<\mathrm{pH})$, which is reflected in the surface potential $\left(\psi_{0}\right)$. The $\mathrm{Cl}^{-}$and $\mathrm{Na}^{+}$ions will be attracted when $\mathrm{s}_{\mathrm{H}}$ acquire positive or negative values, respectively, and due to its kinetic energy, they will be distributed to a certain distance of the surface forming the diffuse layer of counter ions $[16,29,32]$.

The adsorption curves of the other studied metals, could also be adjusted to the Gouy-Chapman model. Figure 6 shows an example for the $\mathrm{CsCl} 0.1 N\left(r^{2}=0.9818\right)$. Therefore, the mechanism of ion exchange is likely similar in all the cases, but the diffuse layer will be conformed by cations of the studied metal.

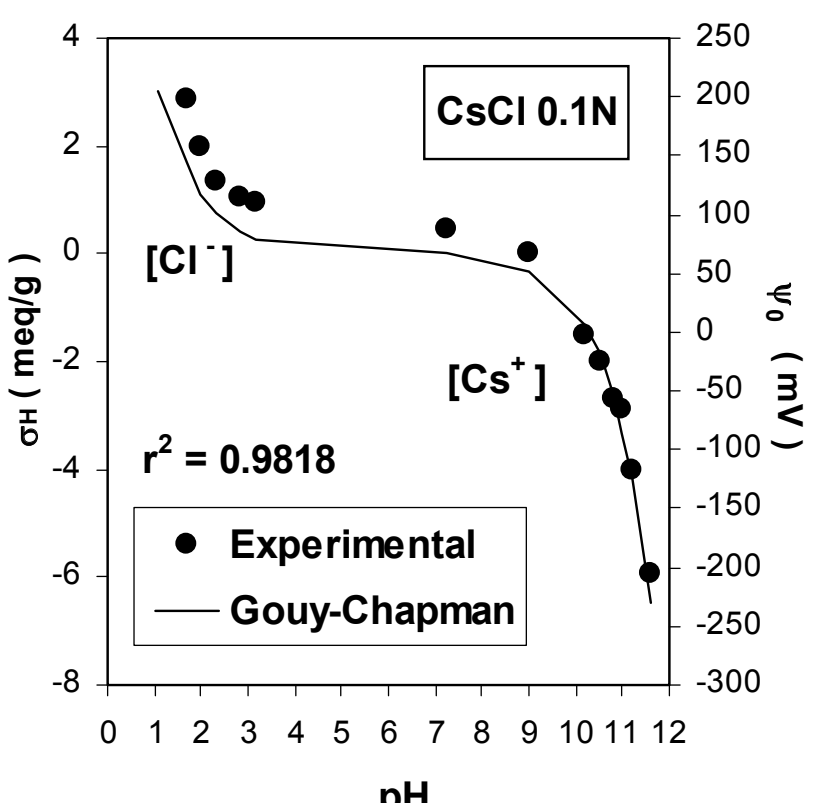

Fig. 6. Comparison of the surface charge of $\mathrm{PCH}$ as determined by potentiometric tritation for $\mathrm{CsCl} 0.1 N$ with that calculated by the Gouy-Chapman theory. $r^{2}$ : determination coefficient; $\sigma_{\mathrm{H}}$ : $\mathrm{pH}$-dependent charge $(\mathrm{meq} / \mathrm{g}) ; \psi_{\mathrm{o}}$ : surface potential $(\mathrm{mV})$.

\section{Conclusion}

The prepared $\mathrm{PCH}$ developed $\mathrm{pH}$-dependent charge probably due to the presence of amphoteric silanol groups forming during the pillared process. The PCH had the capacity to bind alkaline metals ( $\mathrm{Li}, \mathrm{Na}, \mathrm{K}, \mathrm{Rb}$ and $\mathrm{Cs}$ ) at high values of $\mathrm{pH}$ by means of electrostatic interactions. Further studies must carry out to support these findings in the case of heavy metals.

\section{Experimental}

\section{Host Clay}

A bentonite from Mexico was used in this work as host clay for the preparation of a $\mathrm{PCH}$. This clay was chosen because its abundance and low cost in Mexico. In addition, this clay has cationic exchange and swelling properties, suitable for the chemical modification. The sample was supplied by Arcillas Industriales de Durango, S.A. (Durango, México).

\section{Preparation and Characterization of a Porous Clay Heterostructure (PCH)}

The procedure used to prepare and characterize the $\mathrm{PCH}$ was described in a previous paper [24]. The $\mathrm{PCH}$ was prepared using hexadecyltrimethylammonium bromide (HDTMA), dodecylamine (as co-surfactant) and sodium silicate solution; 
all reactants were obtained from Sigma-Aldrich Chemical Co. (U.S.A.).

The structural formula obtained from the chemical analysis of the PCH was $\mathrm{Ca}_{0.12} \mathrm{Na}_{0.04} \mathrm{~K}_{0.04}{ }^{*} \mathrm{Si}_{0.48}\left(\mathrm{Si}_{8}\right)\left(\mathrm{Al}_{2.9} \mathrm{Fe}_{0.20} \mathrm{Mg}\right.$ ${ }_{0.44} \mathrm{O}_{20}(\mathrm{OH})_{4}$.

Characterization of the PCH by X-Ray diffraction and low temperature nitrogen adsorption isotherms, showed a basal spacing d(001) of $2.32 \mathrm{~nm}$, a BET specific surface area of $305.5 \mathrm{~m}^{2} / \mathrm{g}$ and BJH average pore diameter of $3.72 \mathrm{~nm}$.

\section{Determination of the Cation Exchange Capacity (CEC)}

The CEC determination was carried out by the ammonium acetate method [25]. $5 \mathrm{~g}$ of clay was mixed with $20 \mathrm{~mL}$ of $1.0 \mathrm{~N}$ ammonium acetate solution $(\mathrm{pH}=7.0)$. The suspension was stirred for $24 \mathrm{~h}$ with a mechanic stirrer at $25^{\circ} \mathrm{C}$. The mix was filtrated using Whatman paper No. 42, and the clay was washed several times with the same $1.0 \mathrm{~N}$ ammonium solution and finally with anhydrous ethanol. The filtrates were eliminated. The ammonium saturated clay was leached with $10 \%$ potasium chloride solution and the leachates were transferred quantitatively to a $100 \mathrm{~mL}$ volumetric flask. An aliquot of 10 $\mathrm{mL}$ of this last solution was added to $6 \mathrm{~mL}$ of $1.0 \mathrm{~N}$ sodium hydroxide into a Kjeldhal flask and distilled. $40 \mathrm{~mL}$ of distillated were collected in a flask containing $5 \mathrm{~mL}$ of $2 \%$ boric acid solution. This solution was tritated with standard $0.1 \mathrm{~N}$ chlorhidric acid in the presence of red methyl-methylene blue indicator. Blanks of the reagents were also analized. The CEC was calculated as milliequivalents of the ammonium by 100 $\mathrm{g}$ of clay. All reactants were obtained from Sigma-Aldrich Chemical Company (USA).

\section{Potentiometric Titration Curves}

The determination of the $\mathrm{pH}$-dependent charge $\left(\mathrm{s}_{\mathrm{H}}\right)$ of the $\mathrm{PCH}$ was obtained by the potentiometric titration method described by Dyer and Gallardo [15]. Serial titration curves were made mixing $0.2 \mathrm{~g}$ of $\mathrm{PCH}$ with $25 \mathrm{~mL}$ of aqueous solutions containing $(\mathrm{NaCl}+\mathrm{HCl})$ or $(\mathrm{NaCl}+\mathrm{NaOH})$, adjusting the final concentration at $0.1 N$. The process was repeated to obtain a final concentration of $0.01 \mathrm{~N}$ in order to calculate the zero point of charge. All reactants were obtained from Sigma-Aldrich Chemical Company (USA). The mixtures were continuously stirred by an orbital action shaker for $24 \mathrm{~h}$, at $25{ }^{\circ} \mathrm{C}$ (preliminary kinetic experiments demonstrated that adsorption equilibrium was completely reached within $24 \mathrm{~h}$ ). At equilibrium, the suspension $\mathrm{pH}$ of each sample was measured with a $\mathrm{pH}$-meter Hanna HI 2210 (HANNA Instruments, USA). Also, the pH of solution blanks was determined following the same approach.

The amount of $\mathrm{Na}^{+}$or $\mathrm{Cl}^{-}$adsorbed by the $\mathrm{PCH}$ sample at any given $\mathrm{pH}$ value, was calculated from the differences in the concentrations of $\mathrm{OH}^{-}$or $\mathrm{H}^{+}$, between the blank and the sample suspension at the same amount of alkali or acid added to the sample.

The process was repeated for the other single (salt + acid/ base) solutions ( $\mathrm{LiCl}, \mathrm{KCl}, \mathrm{RbCl}$ and $\mathrm{CsCl}$ ) adjusting the final concentration at $0.1 N$. All reactants were from Sigma-Aldrich Chemical Company (USA).

The reported results are the average of triplicate measurements. The error bars shown in the figures represent the standard deviation values.

\section{Acknowledgement}

Financial support from SIP-IPN is appreciated.

\section{References}

1. Duarte-Davidson, R.; Troisi, G.; Capleton, A. A Screening Method for ranking Chemicals by their Fate and Behaviour in the Environment and Potential Toxic Effects in Human Following Non-occupational Exposure. Institute for Environment and Health, Leicester, UK. 2004.

2. Jung, J.; Kim, J.; Suh, J, Lee, J.; Ryu, S. Wat. Res. 2001, 35, $937-$ 942.

3. Aguado, J.; Arsuaga, J. M.; Arencibia, A.; Lindo, M.; Gascón, V. J. Haz. Mat. 2009, 163, 213-221.

4. Beck, J. S.; Vartuli, J. C.; Roth, W. J.; Leonowicz, M. E.; Kresge, C. T.; Schmitt, K. D.; Chu, T. W.; Olson, D. H.; Sheppard, E. W.; Mc Cullen, S. B.; Higgins, J. B.; Schlenker, J. L. J. Am. Chem. Soc. 1992, 114, 10834-10843.

5. Galarneau, A.; Barodawalla, A.; Pinnavaia, T. J. Nature 1995, 374, 529-531.

6. Cool, P.; Ahenach, J.; Collart, O.; Vansant, E. F. Stud. Surf. Sci. Catal. 2000, 129, 409-416.

7. Pichowicz, M.; Mokaya, R. Chem. Commun. 2001, 2100-2101.

8. Pinnavaia, T. J. US patent 1998. (US 5834391)

9. Ahenach, J.; Cool, P.; Vansant, E. F. Phys. Chem. Chem. Phys. 2000, 2, 5750-5755.

10. Polverejan, M.; Liu, Y.; Pinnavaia, T. J. Chem. Mater. 2002, 14, 2283-2288.

11. Li, B.; Mao, H.; Li, X.; Ma, W.; Liu, Z. J. Colloid Interf. Sci. 2009, 336, 244-249.

12. Wei, L.; Tang, T.; Huang, B. Micropor. Mesopor. Mat. 2004, 67, 175-179.

13. Nunes, C. D.; Pires, J.; Carvalho, A. P.; Calhorda, M. J.; Ferreira, P. Micropor. Mesopor. Mat. 2008, 111, 612-619.

14. Dyer, A.; Gallardo, V. T.; Roberts, C. W., in: Zeolites: Facts, Figures, Future, Jacobs, P. A.; Van Santen, R. A. Ed., Elsevier Applied Science, London, 1989, 389-398.

15. Dyer, A.; Gallardo, V. T. in: Recent Developments in Ion Exchange, Williams, P.A.; Hudson, M.J. Ed., Elsevier Applied Science, London, 1990, 75-84.

16. Arellano, C. S.; Gallardo, V. T. López, C. S.; Osorio, R. G. Rev. Soc. Quím. Mex. 2002, 46, 120-124.

17. Stamberg, K.; Venkatesan, K. A.; Rao, V. P. R. Colloids Surfaces A 2003, 221, 149-162.

18. Helmy, A. K.; Ferreiro, E. A.; De Busseti, S. G. Clays Clay Miner. 1994, 424, 444-450.

19. Puanngam, M.; Unob, F. J. Hazard. Mater. 2008, 154, 578-587.

20. Heidari, A., Younesi, H., Mehraban, Z. Chem. Eng. J. 2009, 153, 70-79.

21. Mercier, L.; Pinnavaia, T. J. Micropor. Mesopor. Mater. 1998, 20, 101-106.

22. Bejenlloun, M.; Cool, P.; Linssen, T.; Vansant, E. F. Micropor. Mesopor. Mater. 2001, 49, 83-94.

23. Tassanapayak, R.; Magaraphan, R.; Manuspiya, H. Adv. Mater. Res. 2008, 55-57, 617-620. 
24. Arellano, C. S.; Osorio, R. G.; Gallardo, V. T.; López, C. S. Rev. Soc. Quím. Méx. 2003, 47, 240-244.

25. Bain, D. C.; Smith, B. F. L. in: A Handbook in Determinative Methods in Clay Mineralogy, Wilson, M. J. Ed., Blackie, Glasgow, 1987, 111-120.

26. Grim, R. E.; Kulbichi, G. Am. Miner. 1961, 56, 1329-1333.

27. Goyne, K. W.; Zimmerman, A. R.; Newalkar, B. L.; Komarneni, S.; Brantley, S. L.; Chorover, J. J. Porous Mater. 2002, 9, 243256.

28. Parks, G. A. Chem. Rev. 1965, 65, 177-198.
29. Gast, R. in: Minerals in soil environments. Dixon, J. B.; Weed, S. B.; Kittrick, J. A.; Milford, M. H.; White, J. L. Ed., Madison Wisconsin, USA, 1977, 27-73.

30. Tran, H. H.; Roddick, F. A.; O’Donell, J. A. Wat. Res. 1999, 33, 2992-3000.

31. Yang, R. T. Adsorbents. Fundamentals and applications. Ed., John Wiley \& Sons Inc., New Jersey, 2003.

32. Van Raij, B.; Peech, M. Soil. Sci. Soc. Amer. Pro. 1972, 36, $587-$ 593. 